\title{
Zsoldos Attila*
}

\section{AZ ERDÉLYI LÁZADÓ: ÁKOS NEMBÉLI MOJS}

\author{
Kulcsszavak: tartományúr, politikai karrier, családi kapcsolatok, lázadó
}

Nehéz szabadulni attól a gondolattól, hogy mennyivel árnyaltabb lenne tudásunk a magyar középkorról, ha forrásaink túlnyomó része nem a királyi udvar írásbeliségéhez kötődnék. Különösen fontos lenne, hogy ismereteink több forrásból származzanak azon esetekben, amikor nyilvánvaló: a királyi udvar írásbeliségének ránk maradt emlékei csupán az érem egyik oldalát tárják elénk, számunkra viszont fontos lenne a másikat is szemügyre venni. Ez azonban többnyire jámbor óhaj marad, így bele kell törődnünk, hogy hiányos és egyoldalú képet rajzolhatunk csupán a királyi hatalom ellenfeleiről.

Az Erdély történetében a 14. század első évtizedeiben jelentős szerephez jutó Ákos nembéli Mojsról például azt tudjuk, hogy ki volt, azt azonban, hogy mi, jóval kevésbé. Személyének megbízható azonosítása sem túlságosan régi keletű mindazonáltal: a 19. század végén még különféle elképzelések éltek ezzel kapcsolatosan. Mivel apja neve is bizonyosan Mojs volt, kézenfekvőnek tűnt az 1280-ban meghalt Mojs nádor ${ }^{1}$ fiának tekinteni - miként azt többen meg is tették ${ }^{2}$-, jóllehet már akkor sem volt ismeretlen a tény, hogy az említett Mojs nádor minden ismert gyermeke leány, fiai nem is születtek. ${ }^{3} \mathrm{Az}$ erdélyi lázadó apjára és nagyapjára vonatkozó adatokat már Wertner Mór összekapcsolta egymással, ${ }^{4}$ ám anélkül, hogy a tágabb rokonságot jelentő Ákos nemzetségig eljutott volna. Ezt a lépést Makkai László tette meg, ${ }^{5}$ megoldási javaslata azonban Karácsonyi János személyében - méltán élvezett tekintélyére hivatkozva - visszautasításra talált, ${ }^{6}$ pedig az Ákos nemzetség címerének beha-

* Zsoldos Attila (1962), akadémikus, történész, az MTA Bölcsészettudományi Kutatóközpont Történettudományi Intézetének tudományos tanácsadója, témacsoport-vezető, Budapest. E-mail: zsoldos.attila@btk.mta.hu.

1 Személyére lásd Wertner Mór: II. Moys nádor és családja. Századok XXV(1891). (a továbbiakban Wert ner: II. Moys nádor) 392-405; Szovák Kornél: Mojs = Korai magyar történeti lexikon (9-14. század). Főszerk. Kristó Gyula, szerk. Engel Pál-Makx Ferenc. Akadémiai, Bp., 1994. 462 (további irodalommal).

2 Bunyitay Vince: Kopasz nádor. Életrajz a XIII-XIV. századból. Századok XXII(1888). 141; Koмáromy András: Dózsa nádor és a Debreczeni család. Turul IX(1891). 6.

3 Wertner: II. Moys nádor 403-405.

4 Wertner Mór: Az Árpádkori megyei tisztviselök. Okirati kútfő́k nyomán (harmadik és befejező közlemény). Történelmi Tár 1898. 116; Uő: Az Árpádkori bánok. Meghatározások és helyreigazitások (második közlemény). Századok XLIII(1909). 481.

5 Maккаi László: Belsö-Szolnok és Doboka megye a középkorban = Szolnok-Doboka magyarsága. Szerk. Szabó T. Attila. Dés-Kvár, 1944. 63.

6 Mályusz Elemér: Az erdélyi magyar társadalom a középkorban. MTA TTI, Bp., 1988 (Társadalomés művelődéstörténeti tanulmányok 2). 88. (64. jegyz.) (A mű 1947-ben készült.) 
tó vizsgálata utóbb egyértelműen igazolta álláspontját. ${ }^{7}$ Ma már általánosan elfogadott, ${ }^{8}$ hogy az erdélyi lázadó az Ákos nemzetségből származott: nagyapja V. István lovászmestere, Albert volt, apja pedig az a Mojs, aki az 1290-es években székelyispánként, majd királynéi tárnokmesterként kerül elénk, ezt megelózően - 1287-1288 táján - pedig talán erdélyi vajda is volt. Ez utóbbi adat bizonytalanságát az okozza, hogy idősebb Mojs kizárólag egy hamis oklevélben tünik fel Erdély vajdájaként, a körülmények azonban nem teszik teljesen valószínútlenné, hogy legalább e vonatkozásban a szöveg az egykor volt valóságot tükrözi. ${ }^{9} \mathrm{Az}$ idősebb Mojs két fivérérôl tudunk, Jánosról és Ákosról. ${ }^{10}$

A következő generáció családi viszonyait illetően - a lehetőségekhez mérten - szintén viszonylag tájékozottnak mondhatjuk magunkat. Az idősebb Mojs három gyermekét ismerjük: egyikük Mojs, az erdélyi lázadó, másikuk ennek fivére, Ellős - azaz nyilván Achilles -, s a fivéreknek volt egy leánytestvérük is, aki bizonyos Sárpataki Andráshoz ment férjhez. A házasságból, mely legkésőbb 1307 táján jöhetett létre, két fiú született. Sárpataki András 1318-ban már nem élt, fiai gyámjaiként ifjabb Mojst és Ellőst említik, akik ekkor sógoruk birtokai közül a Doboka megyei Simontelkét egy besztercei polgárnak adták át arra hivatkozva, hogy azt András még életében neki ígérte szolgálatai fejében. ${ }^{11}$ Sárpataki András birtokai egyébiránt széles sávban nyúltak el Doboka, Kolozs és Torda megyéken keresztül, néhány év múlva 22 birtokot sorolnak fel az uradalom részeiként. A birtoknevek azonos voltából ítélve Sárpataki András minden bizonnyal azonos személy volt azzal az Ipoch fia Andrással, akinek birtokait - mivel László volt vajda oldalán hútlenségbe esett - 1319-ben I. Károly Szécsényi Tamásnak, akkor még szerémi, bácsi és aradi ispánnak adományozta. ${ }^{12}$

Az apai név birtokában lehetségesnek tünik az egyébként ismeretlen Sárpataki András eredetének meghatározása. 1268-ban ugyanis a Torda megyei Toldalag egyik szomszédjaként bizonyos Ypoch bán fia Ypona nevú személyt említenek ${ }^{13}$ - márpedig Sárpatak Toldalaggal délről szomszédos -, Sárpataki András említett Simontelke nevú birtokának tartozékaként viszont egy Ipona nevú erdő szerepel 1318-ban, ${ }^{14}$ végezetül pedig a 13. század elejének bárói

7 RÁcz György: Az Ákos nemzetség címere. Turul LXVII(1995). 11-34.

8 Engel Pál: Magyarország világi archontológiája 1301-1457-Középkori magyar genealógia. (Magyar Középkori Adattár) CD-ROM. Bp., 2001. (Ákos nem 3. Erne ága)

9 Zsoldos Attila: Magyarország világi archontológiája 1000-1301. História-MTA TTI, Bp., 2011 (História könyvtár - Kronológiák, adattárak 11) (a továbbiakban Zsoldos: Archontológia). 282, 338. Az idősebb Mojs erdélyi vajdaságára lásd még uo. 40. (284. jegyz.)

10 1278. s. d.: Magyar Nemzeti Levéltár Országos Levéltára (a továbbiakban MNL OL), Diplomatikai Levéltár (a továbbiakban DL) 29659.

11 1318. jún. 3.: DL 29 421., kiadását lásd GyörfFY György: Gyulafehérvár kezdetei, neve és káptalanjának registruma. Századok CXVII(1983).1130-1131.

12 1319. júl. 28.: Urkundenbuch zur Geschichte der Deutschen in Siebenbürgen. I-VII. Bearb. von Franz Zimmermann-Carl Werner et al. Hermanstadt-Köln-Wien-Buc., 1892-1991. (a továbbiakban UGDS) I. 340-341.

13 1268. s. d.: Erdélyi okmánytár. Oklevelek, levelek és más írásos emlékek Erdély történetéhez. I-II. Bevezető tanulmánnyal és jegyzetekkel regesztákban közzéteszi Jakó Zsigmond. Akadémiai-MOL, Bp., 1997-2004; III. Regesztákban jegyzetekkel közzéteszi Hegri Géza és W. Kovács András közremúködésével †Jакó Zsigmond. MOL, Bp., 2008; IV. Jakó Zsigmond kéziratát szerkesztette és kiegészítette Hegri Géza-W. Kovács András. MNL MOL-MTA BTK, Bp., 2014. (a továbbiakban EO) I. 272. sz.

14 1318. jún. 3.: DL 29 421., GYöRFFY: i. m. 1130. 
között ismerünk egy Ipoch nevű szlavóniai bánt, majd erdélyi vajdát, aki minden valószínűség szerint azonosítható a Bogátradvány nemzetség egyik tagjával. ${ }^{15}$ Egyáltalán nem lenne meglepő tehát, ha Ákos nembéli Mojs sógora, Sárpataki András valójában Bogátradvány nembéli Ipoch fia Ipona fia Ipoch fiaként lenne azonosítható, ami mindenesetre magyarázatot kínálna jelentős vagyonának eredetére. Kétségtelen azonban, hogy ennek a meghatározásnak vannak gyenge pontjai: Ipoch bán Bogátradvány nembéli volta nem áll sziklaszilárd alapon, miként az Ipoch fia Iponát említő 1268. évi oklevél hitele sem. ${ }^{16}$

Akármi is a helyzet Sárpataki András származásával, az bizonyos, hogy az Ákosok jól adták férjhez idősebb Mojs leányát. Ismert erdélyi birtokaik ugyanis jóval szerényebb méretűek voltak, mint a sárpataki uradalom. A rendelkezésünkre álló adatok szerint a Doboka megyei Buza, Noszoly és Lak, valamint a Kolozs megyei Budatelke az idősebb Mojs fiainak, Mojsnak és Ellősnek az örökölt birtokai voltak, míg el nem kobozták azokat, ${ }^{17}$ a Kolozs megyei Földvárról, Cégről és Katonáról pedig azt tudjuk, hogy a fivérével, Mojssal megejtett osztály után kerültek Ellős kezére, hogy aztán utóbb Losonci Dénes fia Tamás birtokaiként kerüljenek elénk, nyilván azt követően, hogy a király azokat is elkobozta, és Tamásnak adományozta. ${ }^{18}$ A Földvárra, Cégre és Katonára vonatkozó megjegyzés alapján megkockáztatható talán az a feltevés, hogy az említett osztály során Buza, Noszoly, Lak és Budatelke juthatott Mojsnak. A fivérek közös birtoka lehetett a Bihar megyei Mojspályi, mely elkobzása után Debreceni Dózsáé lett királyi adományból. ${ }^{19}$ Ismerünk azonban olyan birtokokat is, melyeket a testvérek egyike a másiktól függetlenül birtokolt: így kapta adományul Mojs valamikor 1313-1314 táján Petresfalvát, ${ }^{20}$ egy 1319. évi oklevél szerint pedig a Küküllő megyei Bonyha birtok viszont Ellős kezén volt, bár azt az említett Losonci Dénes fia Tamás székelyispán a maga birtokának tudta, s tiltotta Ellőst attól, hogy a birtokot bármi módon bevonja abba az egyezkedésbe, amelyet Erdős fia Miklós kecskési várnaggyal folytat éppen. ${ }^{21}$ Arról, hogy mi volt az egyezkedés tárgya, éppúgy nem tudunk semmit, mint arról, hogy Bonyha mi módon kerülhetett Ellős kezére, mindenesetre apja, Albert fia Mojs 1278-ig a környéken birtokolta vásárlás címén Dicsőszentmártont, akkor azonban átengedte egy szerviensének annak szolgálatai és némi pénz fejében. ${ }^{22}$

A Sárpataki Andrással létesített házassági kapcsolat tehát a birtokvagyon szempontjából ítélhető jól sikerült lépésnek, az országos politika kapuját pedig házassága nyitotta meg az ifjabb Mojs előtt. Valamikor 1318 előtt vette feleségül Borsa nembéli Tamás fia „Kopasz”Jakab leányát. ${ }^{23}$ Kopasz 1306 és 1314 között I. Károly nádora volt, s mivel Mojssal 1313-1314

15 Zsoldos: Archontológia 309.

16 Vö. EO I. 272. sz.

17 1318. aug. 9.: MNL OL, Diplomatikai Fényképgyűjtemény (a továbbiakban DF) 254779.

18 1327. máj. 31.: Oklevéltár a Tomaj nemzetségbeli losonczi Bánffy család történetéhez. I-II. Szerk. VARjú Elemér-Iványi Béla. Bp., 1908-1928. 59-60.

19 1322. aug. 24.: Anjou-kori okmánytár I-VII. Szerk. NAGY Imre-Nagy Gyula. Bp., 1878-1920. (a továbbiakban AO) II. 45-46.

20 (1313-1314 k.): UGDS I. 300. (Keltére lásd még EO II. 218. sz.)

21 1319. márc. 8.: UGDS I. 338.

22 1278. s. d.: DL 29659.

23 1318. aug. 9.: DF 254779. 
táján királyi pohárnokmesterként és besztercei ispánként ${ }^{24}$ találkozunk - ekkor kapta a már említett Petresfalvát is -, észszerủ feltevésnek tünik, hogy a házasságra valamikor ezen időpont, azaz 1314 előtt kerülhetett sor, a pohárnokmesteri kinevezés pedig a befolyásos após pártfogásának eredménye lehetett. Megerősíti ezt a következtetést, hogy egyfelől az 1314 és 1318 közötti évek a közismert politikatörténeti fejlemények miatt jóval kevesebb valószínúséggel vehetők számításba a házasságkötés időpontjaként, másfelôl pedig egy 1318. évi adat szerint Mojs már akkor Kopasz veje volt, amikor 1316-ban legyőzte Miklós erdélyi vajdát, és a tőle zsákmányolt zászlókat elküldte apósának. ${ }^{25}$

Ezen a ponton el is érkeztünk az ifjabb Mojs lázadóként viselt dolgainak tárgyalásáig, amitől azonban ez alkalommal eltekintek, mégpedig két okból. Egyfelől az események fôbb vonalai jól ismertek: Mojs több alkalommal harcolt I. Károly seregvezérei ellen, részint Biharban apósa, Borsa Kopasz oldalán vagy érdekében, ${ }^{26}$ részint Erdélyben, ahol legalább öt fegyveres összecsapást tudunk kapcsolatba hozni személyével: Miklós vajda legyőzése és kiszorítása Erdélyből, ${ }^{27}$ két ütközet János besztercei és kolozsi ispán ellen először Csicsó vára alatt, másodszor pedig egy hol Gyaluval, hol Gyekével azonosított helység mellett, ${ }^{28}$ csata Debreceni Dózsa vajda ellen Topánál, ${ }^{29}$ és végül csata Losonci Dénes fia István ellen Bonchidánál. ${ }^{30}$ Másfelôl azonban mindezen események részleteivel kapcsolatos ismereteink szerfelett szegényesek, így többnyire vitatottak a közelmúlt és napjaink történeti irodalmában. ${ }^{31} \mathrm{E}$ viták érdemi tárgyalása önálló tanulmányba való, ${ }^{32}$ így ehelyütt inkább Mojs alakjának azon vonásait kísérlem meg felvázolni a következőkben, melyek az eseménytörténet apró, de korántsem jelentéktelen részleteinek tisztázása nélkül is értelmezhetőek (vagy legalább annak tủnnek).

24 Engel Pál: Magyarország világi archontológiája 1301-1457. I-II. História-MTA TTI, Bp., 1996 (História Könyvtár - Kronológiák, adattárak 5). (a továbbiakban ENGEL: Archontológia) I. 2, 43, 111.

25 1318. aug. 9.: DF 254779.

26 1329. máj. 1.: AO II. 404. és 1325. okt. 12.: AO II. 217-218.

27 1318. aug. 9.: DF 254779.

28 1324. ápr. 7.: AO II. 124-126., melynek hiányos szövegét Jakó Zsigmond egészítette ki (EO II. 185., 482. sz.). - A kérdéses helynév értelmezéséhez lásd Kristó Gyula: A korai Erdély 895-1324. Szegedi Középkorász Múhely, Szeged, 2002 (Szegedi Középkortörténeti Könyvtár 18). 318; Uő: I. Károly király harcai a tartományurak ellen (1310-1323). Századok CXXXVII(2003). (a továbbiakban Kristó: I. Károly király harcai) 336 (Gyalu); ill. EO II. 185., 482. sz. (Gyalu vagy Gyeke); vö. még Bárány Attila: Debreceni Dózsa küzdelme a bihari oligarchákkal = Debrecen város 650 éves. Várostörténeti tanulmányok. Szerk. BÁRány Attila-Papp Klára-Szalkai Tamás. Debrecen, 2011 (Speculum Historiae Debreceniense 7). 96. (209. jegyz.)

29 1324. dec. 21.: DL 40 487., kiadását lásd Hóman Bálint: A Magyar Királyság pénzügyei és gazdaságpolitikája Károly Róbert korában. Bp., 1921. (reprint: Bp., 2003.) 255; vö. még 1318. aug. 9.: DF 254 779., 1319. okt. 2.: A zichi és vásonkeôi gróf Zichy család idősb ágának okmánytára. I-XII. Szerk. Nagy Iván-Nagy Imre-Véghelyi Dezső-Kammerer Ernő-Lukcsics Pál. Bp., 1871-1931. I. 173., 1325. máj. 30.: DL 1045.

30 1320. márc. 25.: DF 257787.

31 Vö. Engel Pál: Az ország újraegyesitése. I. Károly küzdelmei az oligarchák ellen (1310-1323). Századok CXXII(1988). (a továbbiakban Engel: Az ország újraegyesitése) 89-146 (passim); Kristó: I. Károly király harcai 297-347 (passim).

32 Zsoldos Attila: Erdélyi háborúk a 14. század elején = Elfeledett háborúk. Középkori csaták és várostromok (6-16. század). Szerk. Pósán László-VeszPrémy László. Zrínyi, Bp., 2016. 198-231. 
Ezek közé sorolható Mojs említett harcainak két szembetűnő jellemzője. Ezek egyike talán úgy foglalható össze a legrövidebben: Mojs nem volt magányos harcos. Ennek jele, hogy a Borsák hozzá csatlakoztak azt követően, hogy a Királyhágótól nyugatra már vereséget szenvedtek a királytól. ${ }^{33}$ Mivel Borsa Kopaszt családi szálak füzték Mojshoz, nincs ebben semmi feltűnő, legfeljebb azt érdemes megjegyezni, hogy a zempléni várait elvesztett Petenye fia Péterrel is ez a helyzet. ${ }^{34}$ Hiba lenne azonban a jelenség magyarázataként arra következtetni, hogy az oligarchák valamiféle egymást segítő koalíciója állt össze az 1310-es évek végén Erdélyben. ${ }^{35}$ Sokkal inkább arról lehet szó, hogy a király már legyőzött kelet-magyarországi ellenfelei utolsó reménységükként tekintettek Mojsra.

Mojs követőinek másik része az erdélyi nemességből került ki. 1319. évi adat teszi bizonyossá, hogy az oldalán harcoltak Zsombor nembéli Lőrinc fia István és fiai, a szintén Zsombor nembéli Cene Mihály fiai, továbbá a Borsa nembéli iklódi Csonka László fiai. ${ }^{36} \mathrm{~A}$ felsoroltak tehetős birtokosoknak számítottak, elsősorban Doboka és Kolozs megyékben, ahová, mint láthattuk, Mojs és fivére, Ellős erdélyi birtokainak a súlypontja is esett. Arra vonatkozóan azonban, hogy az említettek Mojs familiárisai lettek volna, nem rendelkezünk adattal.

A Mojs személyével kapcsolatos erdélyi hadiesemények másik figyelemre méltó vonása, hogy azok kivétel nélkül csaták. Ez annál inkább feltűnő, mert egyébként a királyi hatalom helyreállítása érdekében az oligarchák ellenében vívott harcok legjellemzőbb eseményének, amint az köztudomású, a várak ostroma tekinthető, ${ }^{37}$ ami értelemszerűen következik abból, hogy a várak birtoklása volt az oligarchák hatalmának egyik tartópillére. Nincs azonban egyetlen olyan adat sem a birtokunkban, mely Mojs várát vagy várait említené, amiből aligha vonhatunk le más következtetést, mint azt: ennek az az oka, hogy nem is volt vára. Ez a körülmény kétségkívül megfosztotta Mojsot attól a lehetőségtől, hogy szilárd ellenőrzése alá vonjon valamely régiót, mint tették azt a kor oligarchái a váraik környékén fekvő területekkel, másfelől ugyanakkor egyfajta rugalmasságot biztosított számára. Egy oligarcha ugyanis arra kényszerült, hogy mindenáron megvédelmezze várát (vagy várait), mert ha ez nem sikerült, hatalma összeomlott, amint azt jónéhány példa mutatja, Mojs ellenben hiába szenvedett vereséget Topánál Debreceni Dózsa vajdától, ellenállásának megtöréséhez a bonchidai kudarc is kellett, s talán nem teljesen indokolatlan a gyanú, hogy ez utóbbi csatát is csak az a véletlen körülmény tette döntő ütközetté, hogy a harc során Mojs elesett. Mojsot nem a várából kellett kiostromolni, hanem nyílt ütközetben kellett megverni, mégpedig ott, ahol a csata vállalására rá lehetett kényszeríteni.

Ha mindezek után kísérletet teszünk arra, hogy Mojs alakját felhelyezzük a kor jellegzetes szereplőinek tablójára, könnyebbnek tűnik bizonyos lehetőségek kizárása, semmint a megnyugtató megoldás fellelése.

33 1320. (nov. 8.): DF 251 725. (arra, hogy az oklevélben elbeszélt esemény 1318-ra vonatkozik lásd Zsoldos Attila: A Borsák és I. Károly első összecsapása [sajtó alatt]), 1325. máj. 30.: DL 1045., 1326. máj. 14.: Codex diplomaticus Hungariae ecclesiasticus ac civilis. I-XI. Stud. et op. Georgii FejÉr. Budae, 1829-1844. (a továbbiakban CD) VIII/5. 159.

34 1321. febr. 10.: CD VIII/2. 293.

35 Vö. ellenben KRisTó: I. Károly király barcai 328-329, 332, 336.

36 1319. jún. 21.: AO I. 520-523., 1323. júl. 29.: DL 1970.

37 A legalaposabban feldolgozott 1310 és 1323 közötti időszakban 80 várostromról és 14 ütközetről van tudomásunk, vö. ENGEL: Az ország újraegyesitése (passim). 
Önmagában az, hogy fegyveres konfliktusba keveredett a királyi hatalommal, még senkit sem tett oligarchává sem a 13-14. század fordulója körüli évtizedekben, sem máskor. Mojs esetében ráadásul a vár birtoklásának hiánya is megerősíti, hogy aligha a kor egyik oligarchájával van dolgunk. Azok a kísérletek, melyek olyan - a 14. század első évtizedeit illetően ismeretlen történetűnek számító - várral próbálják meg kapcsolatba hozni Mojs személyét, mint amilyen például Görgény, ${ }^{38}$ érthetőek ugyan, ha Mojsban is a kor egyik oligarcháját véljük felismerni, de attól még nem lesznek meggyőzőek. Nem sokban különbözik ettől az a megoldás, mely Mojsban egy feltörekvő, az oligarchikus magánhatalom kiépítésének csupán a kezdeti fázisában járó előkelőt lát, aki a Kán László halála utáni politikai helyzetben kívánta kiterjeszteni a maga hatalmát Észak-Erdélyre, ${ }^{39}$ hiszen számos példáját ismerjük az efféle kísérleteknek, de a vár birtoklása - mégpedig már a kezdet kezdetén - mindegyik esetben megfigyelhető, az egyetlen kivételt pedig már csírájában eltaposta két szomszédos oligarcha alkalmi összefogása, s nem volt szükség a királyi hatalom ismételt katonai akcióira, mint Mojs esetében. ${ }^{40}$

Mojs története a 14. század elején, Erdélyben játszódik, így szükségképpen felmerül az a kérdés, hogy milyen kapcsolatban volt Kán Lászlóval, aki 1314 közepéig bizonyosan a tartomány ura volt. A kérdés indokolt voltát alátámasztani látszik, hogy a Mojssal kapcsolatban lévő személyek némelyike esetében kézenfekvőnek tűnik arra gondolni, hogy eredetileg Kán László familiárisai lehettek. Mojs sógoráról, Sárpataki Andrásról feljegyezték, hogy Kán László volt vajdával együtt a király ellen lázadt, és így hütlenségbe esett, ${ }^{41} Z$ sombor nembéli Lőrinc fia Istvánról pedig azt, hogy a Szil nembéliek bizonyos birtokait jogtalanul foglalta el Kán László idején. ${ }^{42}$ Magáról, Mojsról hasonló adattal nem rendelkezünk, de nem is volna hihető, hogy Borsa Kopasz alkalmas vőnek tartotta volna Kán László egyik familiárisát, legyen az bár mégoly előkelő születésű. Mojs és Kán László kapcsolatáról ily módon az az egyetlen forrásunk ad közvetett módon némi tájékoztatást, mely szerint bizonyos Mojs mester 1313. március 7-én Gyulafehérvárott fogott bíróként tevékenykedett. ${ }^{43} \mathrm{Ha}$ az említett „Mojs mester” azonos személy Ákos nembéli Mojssal - ami bizonyíték híján is szerfelett valószínűnek ítélhető -, akkor is csupán arra következtethetünk az esetből: nem volt akadálya annak, hogy Mojs személyesen megjelenjék a Kán Lászlót uraló tartomány legjelentősebb városában, s ott az előkelő és tekintélyes nemesek rendkívülinek semmiképpen sem nevezhető tevékenységével foglalja el magát.

Ha mármost ezt a szegényes információmorzsát összevetjük mindazzal, amit Mojs és a Borsák közötti kapcsolatokról tudunk, az eddig homályos kép tisztulni kezd. Mojs semmiféle nehézséget nem támasztott akkor, amikor a vajdává kinevezett Meggyesi Miklós a Meszeskapun keresztül Erdélybe érkezett, s ott egy bő éven át gyakorolta teendőit. Ennek a jelenségnek az értelmezésekor hiba lenne elfeledni, hogy 1315 augusztusában, Meggyesi Miklós kinevezésekor éppen békés volt I. Károly és a Borsák viszonya, amit Kopasz fivérének, Bekének

38 Engel: Archontológia I. 321; BÁránY: i.m. 81.

39 KRIsTó: I. Károly király harcai 324-325.

40 Vö. Zsoldos Attila: IV. László és a Kállaiak ôsei. A nyíregyházi Jósa András Múzeum Évkönyve XLII(2000). 77-87.

41 1319. júl. 28.: UGDS I. 340-341.

42 1319. jún. 21.: AO I. 523.

43 1313. márc. 8.: DL 31064. 
az éppen ez idő tájt említett királyi tárnokmestersége bizonyít. ${ }^{44}$ Amikor azonban a király és a Borsák viszonyában változás állott be, s a bihari oligarchák az uralkodó elleni felkelés terveit szőtték, Mojs egyszeriben „csalárdul” (fraudulenter) Miklós vajda ellen fordult, s kiüldözte Erdélyből. Az uralkodói hatalommal szembeszálló Kánoknak - az öreg László vajdának, majd utóbb fiainak - Mojs semmiféle segítséget nem nyújtott. A Borsák érdekében - ellentétben a Kánokkal - Mojs több ízben fegyvert fogott. Ott harcolt 1317 februárjában a debreceni csatában, azt követően elfoglalta a Kraszna megyei Valkó várát - mivel azonban utóbb Elefánti Dezső, I. Károly egyik seregvezére Kopasz fiának, Bekcsnek a váraként foglalta azt vissza királyának, világos, hogy Mojs nem a maga számára foglalta el Valkót, ami pedig egy feltörekvő oligarchajelölttől joggal elvárható lenne, kiváltképp, ha nincs még vára $-{ }^{45}$ kísérletet tett a Sólyomkő várában ostromolt Kopasz felmentésére szorult helyzetébőli, ${ }^{46}$ majd menedéket adott a Biharból kiszorult Borsáknak és követőiknek.

Mindezek alapján aligha állhat távol az igazságtól, ha Mojsban mindenekelőtt Borsa Kopasz vejét látjuk. Ez a megközelítés magyarázatot kínál két, egyébként nehezen érthető jelenségre. A Borsák hatalmával a háta mögött Mojs könnyedén megőrizhette függetlenségét Kán László tartományának közepén, jelenléte Erdélyben ugyanakkor lehetőséget teremtett a Borsák számára ahhoz, hogy befolyásuk egy részét a Királyhágótól keletre évtizedekkel azt követően is megőrizzék, hogy le kellett mondaniuk az erdélyi vajdaságról, s tehették mindezt anélkül, hogy nyílt konfliktust kellett volna vállalniuk Kán Lászlóval. A Borsák hatalma tehát az 1310-es években jelen volt Erdélyben, egészen Ákos nembéli Mojs bukásáig.

\section{THE INSURGENT FROM TRANSYLVANIA: MOJS OF ÁKOS KINDRED}

\section{Keywords: oligarch, political career, genealogy, insurgent}

The paper presents the political career of Mojs of Ákos kindred, who was an important actor of the political life of Transylvania in the second half of the first decade of the 14th century. After clarifying his genealogy the author identifies his estates in Kolozs and Doboka counties. As a characteristic of his struggle against king Charles I the author notices the fact that Mojs always faced the king's armies in open battle, because he didn't own any castles. This fact made for him impossible to strictly control a region, as the oligarchs did around their castles, but on the other hand it provided him a kind of flexibility in action. Another characteristic is the fact that he always faced Charles together with his father-inlaw Kopasz of Borsa kindred. From these characteristics the author deduces that although Mojs of Ákos kindred can't be considered an oligarch, based on the support of Borsa kindred he was able to keep his independence in the province of László Kán. His presence in Transylvania also ment that the Borsa kindred succeded to keep a part of his influence in this region even after they had to resign from the office of the Transylvanian voivode.

44 Engel: Archontológia I. 11. és 36.

45 1329. máj. 1.: AO II. 404.

46 1325. okt. 12.: AO II. 217-218. 


\section{REBELUL TRANSILVAN: MOJS DIN NEAMUL ÁKOS}

\section{Cuvinte-cheie: oligarh, carieră politică, relații familiale, rebel}

Studiul schiţează portretul politic al lui Mojs din neamul Ákos, personaj care a avut un rol însemnat în istoria politică a Transilvaniei începând cu a doua jumătate anilor 1310. După analiza relaţiilor familiale a lui Mojs, autorul identifică posesiile obţinute de acesta, marea lor majoritate fiind situate în comitatele Cluj și Dăbâca. Deoarece Mojs nu poseda nici o cetate, caracteristica luptelor lui cu oștirile regelui Carol I. de Anjou a fost acela a bătăliilor deschise. Această circumstanţă a fost principala piedică în achiziţ̧ia și dominarea unor largi teritorii sau regiuni în jurul unei cetăţi, procedeu de altfel larg răspândit printre ceilalţi oligarhi ai vremii, care posedau una sau mai multe cetăţi. Însă datorită acestui fapt Mojs a avut un spaţiu mai liber de mișcare. O altă caracteristică a fost aceea de a înfrunta regele întotdeauna în compania socrului său: Kopasz din neamul Borsa. Din cele două observaţii se ivește următoarea concluzie: Mojs nu reunește întru totul caracteristicile oligarhilor epocii, în același timp oferă explicaţii la două fenomene greu de perceput. Sprijinit de puterea Borseștilor, Mojs putea să păstreze cu ușurinţă independenţa lui în mijlocul regiunii lui Ladislau Kán, totodată prezenţa lui în Transilvania a oferit posibilitatea Borseștilor să păstreze puterea lor în regiune și după ce un membru al familiei a fost privat de funcţia de voievod al Transilvaniei (1294), fără a intra însă în conflict deschis cu actualul voievod: Ladislau Kán. Puterea Borseștilor așadar a fost prezentă în Transilvania anilor 1310 până la înăbușirea rebeliunii lui Mojs. 